\title{
Managing Innovative Trends in Economic Development
}

\author{
Gusev Yuri Vasilyevich \\ Russian Scientific Research Institute "Center" \\ Moscow, Russia \\ gusev.yury@icloud.com
}

Karnaukh Inessa Stanislavovna

Russian University of Economicsthem. G.V. Plekhanov

Moscow, Russia

Karnaukh.is@rea.ru

\author{
Polovova Tatyana Alexandrovna \\ Moscow Metropolitan Governance University \\ Moscow, Russia \\ t.a.polovova@gmail.com \\ Taratina Anastasia Leonidovna \\ Moscow Metropolitan Governance University \\ Moscow, Russia \\ neasty.polovova@mail.ru
}

\begin{abstract}
Technological leaps that occur periodically and replace dominant technologies with more advanced ones lead not only to the reduction of individual production costs below the socially necessary ones, but also provide higher consumer results.

In world practice, one of the important instruments of state policy as an innovative trend in the development of the national economy, as well as individual territorial entities, is the priority implementation of the principles of the so-called green economy. At the centre of the transformation of economic models and transition to a green economy there are technologies based on new methods and processes of production and environmentally oriented policy of the state, consistently ensuring the strategic interests of the national and economic security of the country. The goal of transition to a green economy is not only to improve the quality of life of the world's population while minimizing the depletion of natural resources and preserving nature for future generations, but also to create a significant number of jobs.

However, in practice, this cannot be done without radical reforms and investments in fixed capital, as well as the implementation of appropriate forms of priority, which do not conflict with other tasks of socio-economic development of the country.

The article discusses a number of features associated with the transition of Russia to the formation of a green economy, which are determined by large territories and the heterogeneity of their potential, the issues associated with the transition to the sixth technological mode and the need to have sufficient amount of investment in the key areas of infrastructure, which constitutes the core of the green economy and the involvement of private business in order to attract investment.
\end{abstract}

Keywords: green economy, management, investments, territorial entities, technological structure, national projects, organizational and economic mechanism

\section{INTRODUCTION}

The low level of Russian economy development is a serious problem in ensuring its competitiveness in the modern international space. This situation is primarily conditioned on the extremely unsatisfactory pace of transition to the innovative path of development. In this regard, radical transformations in the economy are still relevant, which are based on an innovative mechanism that provides, firstly, the modernization of the existing economy, secondly, the creation of its new infrastructure with key actors of the innovationoriented sphere (government, business, financial and scientific organizations, universities, etc.), based on the technologies of the 6th technological order, and thirdly, the creation of new ways to attract investments. Through such a mechanism, the prospects for technological development of the relevant industry or technical and technological trends corresponding to the new technological order will be formed.

In this respect, of course, innovative global trends in the world economy result in transformations, adaptability and new positioning of national economies in the global economic space. At the same time, the adaptive properties of national economies are manifested through an increase in their level of innovation.

According to the authors, the provision of innovative activity of the economy in modern conditions should be based on the need to develop theoretical and methodological foundations of the economic mechanism of innovation management in the context of the potential of the 6th technological order and such its trends as an information society on the basis of modern information and communication technologies ("e-governance"), technologies for sustainable energy production from renewable sources, and green economy. The problem methodology includes the issues 
as unsatisfactory. There is a negative dynamics of demand in the country, as well as a number of other negative factors, which are considered in economic literature in sufficient detail, for example [1].

Meanwhile, business structures compete through unique technologies in today's global market of goods and services. Moreover, the service sector takes a significant part in this process, providing stability in the conditions of fluctuation of the world economy.

In this regard, the formation of a model of the national innovation economy is still a problem that requires fundamental changes in the context of the chosen vector of economic development and innovation trends of the world economy.

The key trend of all transformations taking place in national economies is the strategic orientation to the formation of the 6th technological order, which allows to form a technical and technological complex within the unity of the technological method of production, functioning on the ground of the basic technology [2, 3, 4, 5]. It seems that in the future, a model of transition to a new economy, based on global trends, should be formed on the ground of a new technological order.

First direction. There is a process of digitalization and robotization of the production process in industries, economy sectors and social sphere on a global scale through new digital formats and information channels, creating conditions for the formation of a digital government [6]. Currently, there is a process of information development in the form of formation of motivation to the information society on the basis of modern information and communication technologies ("electronic management") [6, 7].

According to experts in this field of knowledge, we can talk about the transition to a new socio-economic formation in the form of a global information society [5, 8, 9, 10], the trend of which is the formation of a set of national information infrastructures. In this regard, a special attention should be paid to the experience of formation support of innovative economy in the Republic of Kazakhstan [11].

Second direction. Breakthrough technologies, which result in qualitative changes in the productive forces and structural changes in the economy. Such technologies lead to structural falls in the cost of production and capital expenditures and, as a consequence, low capital intensity of economic growth, increased efficiency and productivity. In addition, national economies have the opportunity to integrate into global value chains, specializing in the production of new types of products and services. However, to do this, it is necessary to offer innovative products and services to the global market, forming new innovative niches.

Third direction. Development of technologies for environmentally friendly energy production from renewable sources (energy saving technologies, solar energy, hydrogen energy, etc.).

Fourth direction. Formation of a green economy on the basis of innovative technologies that allow to stabilize the
In addition, the state of the financial market (as the main source of investment) and investor confidence in it is assessed 
is not comparable with the performance of the leading countries, which is at least thrice inferior to Western European countries (for example, Germany and France).

To ensure the parity of public and private capital and development of financing mechanisms it is reasonable to provide:

- tax advantages for accelerators and business angels;

- privileges and preferences for business on condition of initiative financing of scientific and technological projects;

- real and high-quality templates for venture transactions;

- instruments that ensure the flow of public money in the later stages of venture investment;

- banking business development by implementing deep transformations that allow to form a segment of highquality borrowers and provide the necessary level of capital to cover the growing risks of innovative projects (including within the framework of national projects);

- implementation of systemic measures to ensure the investment attractiveness for foreign funds (first of all, the sustainable character of existing preferences, including tax holidays, as well as conditions of fair competition, the availability of quality infrastructure for business development, etc);

- strengthening of communication between the federal centre and the regions in the field of investment in terms of solving problems related to the investment climate, as one of the important macroeconomic indicators.

\section{DISCUSSION}

Nowadays there is a need to intensify the innovative development of the national economy. Innovative infrastructure of the national economy can be achieved through a fundamental change in the model of ensuring effective interaction of the government with economic entities, including through the improvement of the investment mechanism as a national project.

Table I summarizes the topics studied by domestic and foreign authors within the framework of the problem. characteristics; the expert community notes the lack of systemic measures to stimulate the commercialization of innovations in the Russian economy. This leads to an extremely slow growth of the resulting indicators of commercialization (the share of technology exports and the share of venture capital investments in GDP, the average check of venture capital). A special place in the promotion of innovations is occupied by the instruments of the venture market, which in the Russian economy have not taken a significant share in the portfolios of private investors. According to Entrepreneurship at Glance (2016), OECD (2015), and Russian Venture Capital Association (2016), the volume of the venture market in Russia (about $0.01 \%$ of GDP) 
development of the economy, focused on the formation of a new technological order [47, 48, 49].

At the same time, the conceptual approach to the formation of an organizational mechanism for creating a new economy based on the innovative trends outlined above should be based on the use of economic laws and conformities in solving the emerging contradictions of the economic system.

\section{CONCLUSION}

The modern situation is characterized by a number of features, among which are the following. First, there is a process of global acceleration of technical and technological development, leading to automation and robotization of processes in production and business (artificial intelligence machines, digital technologies, 3D printers in key technological sectors of the economy and others). Secondly, technologies development for environmentally friendly energy production from renewable sources has intensified. Thirdly, the government actively stimulates $R \& D$ in priority areas of the green economy, followed by the spread on a global scale in order to stabilize the economic. innovation environment is the implementation of new trends in economic development, which is expressed in a rational combination of priorities of science and production on the basis of an innovative approach.

The study conducted shows that an integrated system that provides a sufficiently sustainable development of the economy for the long term in conditions of high variability of the external environment has not been developed. Some elements that are usually considered beyond the system link are emphasized; that also applies to priority national projects.

Thus, despite the fact that certain aspects of innovative development of the economy are elaborated in a relatively high degree complex issues of formation and functioning of the innovation system in the transition period to a new technological order remain poorly studied. Thus, the modern approach to the development of the national economy has a number of significant drawbacks. In particular, the priority directions of innovative development of the national economy in the context of the 6th technological order are not identified. In addition, there is no consensus among authors on the choice of these priorities, and a large part of publications does not present their systematization. Only a few publications are devoted to a more detailed analysis and description of innovative trends, the potential of which will largely determine the degree of economic development in the future. Examples include works by D. Bell, P.Drucker, S. Yu. Glazyev, P. S. Zavyalov, L.M. Gokhberg E. Toffler and others $[25 ; 26 ; 28 ; 29 ; 33]$. We can assume that there may be other points of view on the formation of a new economy.

However, despite the implemented proposals in theory and practice of innovative economic development in the context of global trends and challenges in the field of innovation, there are still a number of unresolved problems. According to authors and economists involved in formation of a fundamentally new national economy, it is necessary to develop a conceptual model of the strategy for innovative

\section{REFERENCES}

[1] Bobrov Leonid, K., Gusev Yuriy, V. Variant of the internal model of underwriting risk for the application of the Solvency II directive Academy of Accounting and Financial Studies Journal Volume 21, Issue 3, November 2017, 6p

[2] Kalashnikov I.B., Vavilina A.V., Yakubova T.N. The new technological mode on the way to the formation of the innovative economy // Creative Economy. - 2018. - Volume 12. - No. 9. - pp. 1307-1320.

[3] Mudrak Ya.O., Pobegailo M.G. New technological storage on the way of innovative economy formation in the aspect of economic security // Bulletin of Youth Science. - 2019. - No. 2. - pp. 23-25.

[4] Faizulin M.I., Innovative processes in the economy in the context of development of new technological orders // Bulletin of Udmurt University. Series Economics and Law. - 2018. - No. 1, Volume. 28. pp. 56-60.

[5] Tulokhonov A., Maksanova L., Budanova D., Karnaukh I.S. Geoecological aspects of the territorial organization of tourist and recreational activities // International Scientific Conference Environmental Science for Construction Industry - ESCI 2018 Series "MATEC Web of Conferences" 2018. P. 05018.

[6] The World Bank. Digital government. Prospects for Russia. The World Bank's Russia Digital Economy Report. Competing in Digital Age: Strategic Challenges for the Russian Federation. 2017. P. 43.

[7] The United Nations E-Government Survey: E-Government for the People, 2018

[8] Bobrov, L. K., Medyankina I.P. Mathematical model of distributed data processing system for information support of innovative cluster works // Communications in Computer and Information Science. 2019. T. 998. P. 64-70.

[9] Bobrov, L. On the Influence of the Conceptual Apparatus on Setting the Tasks of Information Support of Innovation Activities / L. Bobrov, I. Medyankina // Automatic Documentation and Mathematical Linguistics. - 2018. - Vol. 52, No. 2. - pp. 97-107.

[10] Utepbergenov, I. Principles of creation of information support system for innovative economy in the Republic Kazakhstan / Irbulat Utepbergenov, Leonid Bobrov, Irina Medyankina // Economic and Social Development: materials digest of the 28th International Scientific Conference on Economic and Social Development (19-20 April 2018, Paris, France). - P. 271-276. 
[30] Mindeli L.E. Core results of long-term technological forecasting for Russia (Osnovnye rezultaty razrabotki dolgosrochnogo tekhnologicheskogo prognoza Rossii) / L.E. Mindeli, auth. M.A. Motova // Problems of Forecasting. - 2006. - No.5. - P. 97-100. Economy in the Republic of Kazakhstan // Studies in Systems, Decision and Control. 2019. T. 199. P. 515-526.

[12] Guryeva M.A. Evolution of the Concepts of "Greening" and "Green Economy" // Science Prospects. 2014. No. 10 (61). pp. 99-105

[13] Gurieva M.A., Naymushina D.V. Green economy in Russia // Theory and Practice of Social Development, 2015, No. 7 pp. 58-59.

[14] Rodionova I.A., Lipina S.A. Green economy in Russia: model and forecast of development // Fundamental Research. - 2015. - No. 2-24. pp. 5462-5466.

[15] Kalashnikov I.B., Vavilina A.V., Yakubova T.N. The new technological mode on the way to the formation of the innovative economy // Creative Economy. - 2018. - Volume 12. - No. 9. - pp. 1307-1320.

[16] Mudrak Ya.O., Pobegailo M.G. New technological storage on the way of innovative economy formation in the aspect of economic security // Bulletin of Youth Science. - 2019. - No. 2. - pp. 23-25.

[17] Tumarkin O.V., Transformation of the economic structure in the transition to a "green" economy // Information Economy: Development and Improvement Prospects. - 2018. - No. 5 (31). - pp. 151-158.

[18] Faizulin M.I., Innovative processes in the economy in the context of development of new technological orders // Bulletin of Udmurt University. Series Economics and Law. - 2018. - No. 1, Volume. 28. pp. 56-60.

[19] Zhuravleva G.P., Aleksandrova E.V., Karnaukh I.S. Achievements of Russian Nobel Prize Winners born in the Russian Empire, USSR and Russia // XXI Century: Fundamental Sciences and Technologies. Proceeding of XV International Scientific and Practical Conference. 2018. pp. 7-14.

[20] Zhuravleva G.P., Aleksandrova E.V., Karnaukh I.S. On the implementation of scientific and practical work "Achievements of Economic Thought in the Writings of the Nobel Prize Winners in Economics" // Plekhanov Russian University of Economics Scientific Bulletin. 2018. No. 1 (13). P. 30-35.

[21] Baksansky O.E., Golovina V.V., Isayeva K.V., Karnaukh I.S., Razina N.A., Selyanskaya G.N., Shubenkova E.V. Innovative educational technologies in a modern university Chronicles of the Joint Fund of the Electronic Resources «Science and Education». 2017. No. 7 (98). P. 66

[22] Vorozhikhin V.V., Karnaukh I.S. Self-government as a mechanism of science reformation // Samoupravlenie, No. 3, 2019, P.97

[23] Karnaukh I.S., Mikheeva A.S., Ayusheeva S.N., Bardakhanova T.B. Substantiation of the siting of construction facilities in the central ecological zone of the baikal natural area: ecological and economic aspects / International Scientific Conference Environmental Science for Construction Industry - ESCI 2018. S. "MATEC Web of Conferences" 2018. P. 05019

[24] Guseyn B. Magomedov, Elena V. Veretennikova, Sergey V. Ulyankin, Stanislav E. Martynenko, Tatyana G. Ilkevich, Liliya V. Borisova Healthy Lifestyle and Social Networks: Trajectory of Their Intersections in Student Life // Journal of Environmental Treatment Techniques. 2019. Volume 7. Issue 3. Pages 389-393

[25] Bell D., Inozemtsev V. Epoch of social distance (Epokha razobshchennosti). - M.: Postindustrial Society Research Centre, 2007.

[26] Drucker P. Management Challenges for the 21st Century. - M.: Mann, Ivanov i Ferber Publishers, 212. - $256 \mathrm{p}$.

[27] Glaziyev S.Yu. Strategic prerequisites for the Russian economy modernisation and innovation development (Strategicheskiye predposylki modernizatsii i innovatsionnogo razvitiya rossiyskoy ekonomiki). - M.: GUU, 2017. - 274 p.

[28] Knowledge-based Economy in Terms of Statistics: Science, Technologies, Innovations, Information Society (Ekonomika znaniy y terminakh statistiki: nauka, tekhnologii, innovatsii, informatsionnoye obshchestvo) / edited by L.M. Gokhberg. M.: Ekonomika, 2012.

[29] Kondratiyev N.D. General Problems of Economic Statics and Dynamics: a Rough Sketch (Osnovnye problemy ekonomicheskoy statiki i dinamiki: Predvaritelny eskiz). — first edition. — M.: Nauka Publishers, 1991. - $567 \mathrm{p}$.

[31] Porter M.E., Competitive Strategy. Techniques for Analyzing Industries and Competitors / Alpina Publisher. 2019.

[32] Seleznev A.Z. The essence of competitiveness of national economy and its indicators (Sushchnost konkurentosposobnosti natsionalnoy ekonomiki i ee indikatory) / A.Z. Seleznev // Actual problems of economy, accounting, auditing and analysis in modern conditions: Collection of scientific articles by students, post-graduate students and higher-education teaching personnel on the basis of the results of the International Scientific-to-Practice Conference (Moscow, RUDN University, 2018 January 22). Edited by M.V. Petrovskaya, V.Z. Chaplyuka, L.N. Sorokina / Department for economy, accounting, auditing analysis. M.: Nauchny konsultant Publishers. - 2018. - P. 383-390.

[33] Toffler A. The Third Wave 1980. - M.: AST, 2010. - 784 p. (Philosophy).

[34] Freeman C., From the Industrial Revolutions to the Information Revolution. - Oxford, Oxford University Press, 2002.

[35] Schumpeter J.T heory of Economic Development. M .: Progress, 1982.

[36] Van Duijn J.J. The Long Wave in Economic Life. - London., 1983.

[37] Clark G. A Farewell to Alms: A Brief Economic History of the World (Proshchay, nishcheta! Kratkaya ekonomicheskaya istoriya mira) Translated from English by Nikolay Edelman. - M.: The Gaidar Institute publishing house, 2012 . - $304 \mathrm{p}$.

[38] Shumyankova N.V. The role of democratisation of ownership relations in enterprises innovation activity development (Rol demokratizatsii otnosheniy sobstvennosti $\quad \mathrm{v}$ razvitii innovatsionnoy aktivnosti predpriyatiy) // Russian entrepreneurship. — 2006. — Vol. 7. — No. 1. - P. 79-83.

[39] Shumyankova N.V. The role of democratisation of ownership relations in enterprises innovation activity development (Rol demokratizatsi otnosheniy sobstvennosti $\mathrm{v}$ razvitii innovatsionnoy aktivnosti predpriyatiy) // Russian entrepreneurship. — 2006. — Vol. 7. —No. 1. - P. 79-83.

[40] Yakovets Yu.V. Epochal innovations of the 21st century (Epokhalnye innovatsii 21 veka). - M.: Ekonomika, 2004. - 444 p.

[41] Abramova M.I. Factors hindering the development of national innovation sphere : practical aspect (Faktory, prepyatstvuyushchiye razvitiyu otechestvennoy innovatsionnoy sfery: prakticheskiy aspekt) // Modern economy and management: approaches, conceptions, models: Proceedings of the International Scientific-to-Practice Conference / edited by M.I. Abramova - Saratov: Nauka Publishers, 2014. P. 7-12.

[42] Bondareva N.N. Condition and prospects of robotization develoment in the world and Russia (Sostoyaniye i perspektivy razvitiya robotizatsii: v mire i Rossii) // MIR (Modernizatcija. Innovatcii. Razvitie). 2016. Vol. 7. No. 3. P. 49-57.

[43] Ivanov V.V. Innovation paradigm of the 21 st century (Innovatsionnaya paradigma)(second edition) - M.: Nauka, 2015. - 384 p.

[44] Barysheva G.A. Innovation factor and intellectual resource in the Russian economy dynamization (Innovacionnyj faktor i intellektual'nyj resurs v dinamizacii ekonomiki Rossii) / G.A. Barysheva; edited by Yu.S. Nekhorosheva: Tomsk Polytechnic University —-Tomsk: Tomsk Polytechnic University Publishers, 2001. — 221 p.

[45] Vikhansky O.S., Mirakyan A.G. Millennium: managemental anomalies and modern leadership conceptions (Novoe tysyacheletie: upravlencheskie anomalii i sovremennye koncepcii liderstva) // Russian Managemenr Jounal. — 2018. - Vol. 16, No. 1. - P. 131-154.

[46] Zavlin P.N. Estimantion of innovations efficiency (Otsenka effektivnosti innovatsiy) / Zavlin P.N., Vasiliyev A.V. - Saint Petersburg: BiznesPress Publishing house, 1998. — 215 p.

[47] The Long-Term Socio-Economic Development Forecast of the Russian Federation for the period up to 2030 (developed by Ministry of Economic Development of the Russian Federation) - ConsultantPlus.

[48] GusevY. V., Polovova T.A., Karnaukh I. Strategic Focus as a Tool tj Ensure Economic Stability and of Non-Financial Corporations as SocioEconomic Systems in Russian Economy Modern // Journal of Applied 
Economic Sciences, Vol/ XI, Issue 5(43), fall 2016: 968-982 ( ISSN-N 1843-6110, ISSN 2393-5162 - Romania -Scopus)

[49] Gusev Y.V., Polovova T.A., Natalyina T.V., Belkov A.V. Formation of logical structure and strategy of production and economic systems growth // The International Journal of Applied Business and Economic Research, Vol. 14, No. 10 (2016): 311-327 (ISSN : 0972-7302 - India Scopus , Econlit) 